а дополнительное введение групп занятий фитнесом в высших учебных заведениях поможет большому количеству студентов найти себе подходящую разновидность физической активности. $3,2016$.

${ }^{1}$ Еникеева А.Р., Хабибуллина А. С. Фитнес в системе физической культуры // Новаинфо. №53-

2 Виды фитнеса, плюсы и минусы тренировок [Электронный ресурс]:http://infitness.ru/poleznoe/chto-takoe-fitnes-kakie-vidy-fitnesa-sushchestvuyut-ikh-plyusy-i-minusy

${ }^{3}$ Тимохина Д. М., Бойцова И. В. Фитнес-гимнастика как перспективное направление в системе преподавания дисциплины “Физическая культура” в ВУЗе // Проблемы и перспективы развития образования в России. 2015. №33. С. 105-109.

\title{
FITNESS IN THE DEVELOPMENT OF THE STUDENTS'S HEALTHY LIFESTYLE FOR STUDENTS
}

\author{
(C) 2020 Shikunova Valeria Alexandrovna \\ Student \\ Samara State University of Economics \\ E-mail: lerashikunova@bk.ru
}

Keywords: fitness, sports, fashion trends, aerobics, shaping, healthy lifestyle.

The article discusses the main features and characteristics of one of the types of physical activity fitness. Identified problems associated with the lack of interest of young people in maintaining a healthy lifestyle. The positive aspects of fitness for students are presented, and the role of fashion trends in the development of enthusiasm for this sport is described.

УДК 796

Код РИНЦ 77.00.00

\section{ДОПИНГ И ЕГО НЕГАТИВНОЕ ВЛИЯНИЕ НА ОРГАНИЗМ СПОРТСМЕНА}

\author{
(C) 2020 Шпатаковская Дарья Александровна* \\ студент \\ Самарский государственный экономический университет \\ E-mail: dasha_d44@mail.ru
}

Ключевые слова: допинг, анаболические стероиды, спорт, здоровье, препараты.

В данной статье рассматриваются виды допинга, описываются его влияние на организм спортсменов и последствия, оказывающие негативное влияние на здоровье.

* Научный руководитель - Налимова Марина Николаевна, старший преподаватель. 
В настоящее время одной из главных проблем в спорте является допинг, что с английского слова "dope" означает наркотик. Согласно МОК допингом могут считаться препараты, которые попадают в организм с помощью инъекций, таблеток, ингаляций и т. д. для достижения лучших результатов. Содержание данных веществ или их остатков при допинговом тестировании спортсмена должны быть точно определены в биологических жидкостях человека. Также не разрешено проводить никаких манипуляций с ними.

1958 год является важнейшим для допинга в спорте, так как в это время врач Джон Зиглер впервые применил Динабол (стероид с пониженной активностью). Этот момент стал переломным для спорта, так как спортсменами все чаще стали употребляться различные запрещенные вещества.

В настоящем времени есть много свидетельств и фрактов, что употребление наркотических препаратов глубоко проникло в разные виды спорта. Различные стимуляторы принимают не только взрослые, но и подростки, которые особенно опасны для здоровья в их возрасте. В связи с этим лекции о вреде допинга ${ }^{1}$ начинают проводиться у детей младших возрастов.

Допинг подразделяют на: наркотики, бета-блокаторы, диуретики, стимуляторы, различные гормональные средства и стероиды.

Также существуют такие допинговые методы, как кровяной допинг и различные манипуляции с биологическими жидкостями (сюда также относится и подмена проб спортсмена).

Еще спортивные допинги² можно разделить по достижению эфффекта на вещества, которые употребляются во время соревнований для получения кратковременного эффекта и вещества, которые предназначены для длительного употребления, так как они имеют накопительный эффеект.

Механизмы их действия

1. Стимуляторы ЦНС.

Препараты этой группы повышают концентрацию внимания спортсменов, делают их более выносливыми, бодрыми, уменьшают чувство усталости, вызывают агрессию и возбуждение, что в конечном итоге может привести к несчастному случаю или смерти из-за воздействия и неспособности здраво оценить происходящее 3 .

К этой же группе допингов относятся и симпатомиметические амино-препараты, повышающие работоспособность организма за счет работы в центральной регуляции вегетативных систем.

2. Наркотические анальгетики

Кодеин, марихуана, промедол и т. д. - наркотические вещества, имеющие анальгезирующий эффрект, содержат в себе примерно 60 препаратов в чистом виде и выявлены примерно в 1,5 тыс. различных лекарственных форм.

Данные препараты направленны на кратковременное снятие боли у спортсменов. Однако эти вещества только вредят здоровью человека, так как помимо различных побочных действий они только маскируют боль, а не лечат ее причину, что в дальнейшем может привести к различным осложнениям, инвалидности и уходу из спорта.

3. Анаболические стероиды.

Анаболические стероиды - это искусственно синтезированные производные мужского полового гормона - тестостерона (в том числе сам тестостерон и его эфиры). 
Долгосрочный прием анаболических стероидов оказывает влияние на печень и желчные протоки, что в конечном итоге приводит к таким болезням, как рак, желтуха, непроходимость желчевыводящих путей и возможен летальный исход. Также возможны различные эндокринные нарушения, оказание негативного влияния на углеводный и жировой обмен. Приему АС сопутствует снижение сексуальной активности и различные психические изменения: депрессия 4 , нервозность, агрессия, повышенная возбудимость и т. д.

4. Бета-блокаторы.

Данные препараты воздействуют на симпатическую нервную систему и ослабляют ее влияние на различные органы. Также они оказывают влияние на сердечную деятельность приводя к снижению силы и частоты сердечных сокращений, повышают тонус бронхов и сосудов.

5. Диуретики.

Новая группа препаратов-диуретиков была включена в запрещенный список МОК в 1986 г., так как она способствует быстрому похудению.

Такая процедура, как допинг крови приводит к различным осложнениям, аллергии, сыпи и т. д. Данный метод является причиной появления желтухи, гепатита, лихорадки, вирусных заболеваний (при неправильном заборе и переливании крови) и возможна перегрузка кровообращение и шок. Относительно недавно на допинговом рынке появился новый препарат - эритропоэтин, стимулирующий образование клеток в крови.

1 РУСАДА (Электронный источник): Антидопинг-курс.

${ }^{2}$ Морозов В.И., Косолапов В.А., Федорович С.В. Допинг в спорте: Методическая разработка. // MH., 1989 г.

${ }^{3}$ Белова Е. И. Психостимуляторы // Основы нейрофармакологии: Учеб. пособие для студентов вузов. - М.: Аспект Пресс, 2006. - С. 120. - 176 с. - ISBN 5-7567-0403-5.

4 В. Н. Залесский, О. Б. Дынник. Побочные эфрфекты действия анаболических андрогенных стероидов (рус.) = Спортивная медицина, №1 // Национальный научный центр "Институт кардиологии им. акад. Н. Д. Стражеско": Статья. - Киев: АМН Украины, 2007.

\title{
DOPING AND ITS NEGATIVE IMPACT ON THE ATHLETE'S BODY
}

\author{
(C) 2020 Shpatakovskaya Daria Alexandrovna \\ Student \\ Samara State University of Economics \\ E-mail: dasha_d44@mail.ru
}

Keywords: doping, anabolic steroids, sports, health, drugs.

This article discusses the types of doping, describes its impact on the body of athletes and the consequences that have a negative impact on health. 